\title{
Effective cost-sharing models in higher education: Insights from low-income students in Australian Universities
}

\author{
CHRISTOPHER JAMES RASMUSSEN \\ Center for the Study of Higher and Postsecondary Education, University of Michigan, \\ 610 E University, SEB 2117, Ann Arbor, MI 48109, USA
}

\begin{abstract}
This study examines the global trend in shifting university costs from national governments to individual students and families, with a specific focus on the existing cost-sharing model in Australian higher education. The research examines the manner in which the availability of income-contingent loans (through the Higher Education Contribution Scheme, or HECS) enters into individual cost assessments and evaluative frameworks during the university exploration and search process of lowincome Australian youth, and the resulting lessons that might be applied to other national contexts. Semi-structured interviews with 16 participants addressed a broad range of issues related to the development of educational aspirations, and how beliefs and attitudes about cost influenced participants' understanding and decision-making regarding tertiary enrollment and post-graduate plans. A number of discreet and related themes emerged from analysis of the interviews, including motivations for attending university; pre-university cost considerations; self-assessments of skills, abilities, and personal traits and characteristics; general financial orientation; pre-university experiences and influences; and the role of others including family, peers, teachers and other school staff. The author concludes that the Australian system is worthy of consideration by other nations as a possible mechanism for enhancing access to higher education for individuals who might otherwise not possess the opportunity to participate.
\end{abstract}

Keywords: affordability, cost-sharing models, finance, income-contingent lending, lowincome students, public policy, student access, student loans.

\section{Introduction}

The rising cost of higher education is a significant and growing public policy issue facing governments around the world. Many nations are struggling with the conundrum of how to expand educational access in an era of smaller governments, shrinking tax bases, and growing demands on federal budgets. This is made more difficult given changing beliefs regarding the relative mix of private and public returns to higher education, and an increasing 'user pays' philosophy to match the growing conviction that the individual is the primary benefactor of 
university-level study (Johnstone and Shroff-Mehta 2000; Marginson 1993, 1997; OECD 1998).

Consistent with this change is a global trend of shifting an increasing percentage of educational costs from governments to individual students and their families (Johnstone and Shroff-Mehta 2000; Vossensteyn 2001). Within this context, researchers and policy analysts are devoting increasing attention to the growing worldwide use of student loans to fund higher education and the various types of cost recovery plans in use or under consideration in various countries, including graduate taxes and income-contingent repayment.

The Australian system, known as the Higher Education Contribution Scheme (HECS), is a relatively well-known and respected financing model that is designed to help the federal government recover a portion of instructional costs while helping to minimize the number of students who are kept away from universities because of an inability to pay. The scheme allows students to defer all tuition until after graduation, at which point fees are repaid through an income-contingent tax. The accumulated debt does not accrue interest but is subject to an annual adjustment for inflation. Since its introduction in 1989, HECS has enabled the Australian government to significantly expand the number of available student places in public universities without decreasing access for individuals with fewer resources. While students from lower socioeconomic backgrounds continue to be underrepresented in Australian higher education relative to their middle- and high-SES peers, their total numbers increased by almost 30\% between 1991 and 2001, a rate comparable to the rise in overall undergraduate student enrollment during the same period (DEST 2002).

The Australian system can serve as a source of insight and guidance for policy makers who are seeking solutions to new or perennial issues related to higher education access and equity. While HECS has been criticized by student advocacy groups and others within Australia as representing a financial obstacle to university participation for those least able to afford it, numerous studies on the potential enrollment effects of HECS have concluded that the system has had little to no negative influence on access by the socioeconomically disadvantaged.

Most of the existing research on the impact of the Australian system has utilized aggregate data from university applications and enrollments, and relied primarily upon quantitative and econometric analyses in determining the relative influence of HECS on student decision making. This paper attempts to address a gap in the current literature base by reporting the results of a qualitative study designed to assess the 
extent and manner by which HECS and related issues of cost serve to influence the attitudes and behavior of low-socioeconomic students attending Australian universities. Interviews with 16 students at four institutions served as a mechanism for revealing insight into the following: How do perceptions of costs influence decision making about university attendance in Australia? How does the prospect of significant postgraduation debt affect the university application and enrollment behavior of Australians? What is the realistic limit of HECS and related educational fees? What can be learned from the experience of Australian students to help promote class-based educational access and equity objectives in other countries?

\section{Conceptual framework}

Ironically, while class inequality is seemingly one of the more intractable problems in higher education, it is also one of the most extensively researched issues affecting the academy. For example, studies conducted in the American context have proposed that high cost, inadequate financial assistance, poor school preparation, discrimination, motivational deficits, the lack of role models or encouragement in the home, and a variety of other psychological, sociological, cultural, economic, and structural variables all play a role in preventing greater numbers of low-income students from attending university.

Australian researchers have similarly proposed that a variety of factors influence the development of tertiary-level educational aspirations of school students and contribute to the continuing socioeconomic gap in university participation. For example, in developing the conceptual framework for their study of rural and isolated students, James et al. (1999) note that studies of the tertiary decision process in Australia have collectively proposed that a combination of psychosocial, socioeconomic, and personal factors influence the development of individual attitudes toward higher education. James et al. draw heavily upon the seminal work of Carpenter and Western (1984), who proposed a causal ordering of the variables affecting student decision making regarding higher education, beginning with a student's social origins and school experience and continuing with the influence of significant others, self-assessments of one's abilities and needs, an individual's future plans and aspirations, and one's academic achievement.

In another important work in the Australian literature on higher education choice and transition, Heyden and Carpenter (1990) 
proposed a person-interactionist theory to help explain the tertiary decision and entry process. In their study of high school students in two states, the researchers found that individual attributes such as academic achievements and motivation, and situational characteristics such as the home environment, school, peers, public policies and work opportunities, combined to influence the school to higher education transition. The predictors of college or university enrollment that emerged from the data included final school year academic achievement; encouragement from parents and teachers for tertiary study; the postsecondary plans of peers; parental wealth and education; and attendance at a non-Catholic private school. Similar themes appeared in two recent studies sponsored by the Australian Council for Educational Research (Lamb 2001; Lamb and McKenzie 2001), in which it was found that individuals who completed tertiary qualifications - including either a university degree or a technical diploma - were more likely to be female, graduates of private schools, from higher socioeconomic backgrounds, from urban areas, and have parents with postsecondary educations.

Among the sociological factors that may prevent more low-income students from attending university - in spite of the availability of deferred tuition and income contingent repayment - is the general unwillingness by some people to assume significant levels of debt to fund their postsecondary studies. Researchers and student advocates have suggested that certain individuals and groups may possess greater levels of debt aversion, and thus exhibit hesitancy toward borrowing large sums of money to invest in higher education. For example, Hauser (1992) and Baker and Valez (1996) imply that in the United States, African Americans and low-income families, respectively, are less willing to assume financial risks, which leads them to avoid incurring debt as a means of financing university study. However, Andrews (1999) found that the prospect of significant future debt did not serve as a discriminating factor influencing the academic choices of potential university students in Australia, as individuals from lower SES groups appeared to be no more debt averse than students of greater financial means when examining patterns in applications for mortgages and other personal loans. Andrews concluded his study by stating

It appears that a possible reason why HECS appears to have had little, if any, effect on the social composition of the student population is that the primary reason underlying the low participation by low SES groups in higher education relates to values and 
attitudes toward higher education (emphasis added) and not financial considerations (p. 25).

Johnstone (2001b) suggests that for low-income, rural, and ethnic minority students, an aversion to debt may exist more as conventional wisdom that as an empirically proven phenomenon, and that debt aversion may represent less of a psychological barrier to participation in higher education if the risks inherent in conventional, mortgage-type loans are minimized. While further research into this critical issue is clearly needed, a closer examination of the effectiveness and efficacy of income contingent loans within the Australian context can provide insight into how the unique program in existence in that country might serve as a source of information and guidance for other nations considering such a mechanism to advance equity and access goals within higher education.

\section{The Australian context}

The Australian higher education system consists of 42 degree granting universities, the vast majority of which are public. The system is largely federally controlled, with the national government playing a significant role in setting student enrollment quotas, establishing tuition rates, and providing institutional funding. While tuition varies by academic program it is consistent across institutions, so that a student in an Arts course, for example, pays the same tuition at any public university in the country.

After a 15-year period where no tuition was charged in Australia universities, the Higher Education Contribution Scheme (HECS) was introduced in 1989. HECS initially required most undergraduate students to pay an annual fee of 1800 Australian dollars ${ }^{1}$ for their university education. The Wran Committee on higher education had argued for a student contribution related to the cost of undergraduate instruction, eventually settling for a fixed rate of $23 \%$ of the average course cost (Karmel 1999). In order to avoid disadvantaging individuals of lesser means, the fee was deferred until students graduated from or left the university. Students who were able and chose to pay the fee upfront were given a $15 \%$ discount. Deferred fees did not accumulate interest, but were annually adjusted by an amount equal to the rate of inflation. Repayment was made through a HECS payroll tax and contingent upon income. While no payment was required until a student 
earned over $\$ 22,000$ annually, an amount of up to $3 \%$ of one's total income was deducted from his/her paycheck depending on the level of earnings above the minimum payment threshold.

Various adjustments in the HECS system have been made since its introduction. The discount for paying fees up-front was increased to $25 \%$ in 1993. A number of changes were made to the system in 1996, including the lowering of the income threshold for repayment; a maximum contribution of $6 \%$ of gross earnings; and the introduction of a three-tiered differential fee structure, with student charges assigned to individual courses based on instructional costs, the earnings potential of graduates, and the general popularity of the course. HECS charges have since been adjusted annually, with fees for the 2004 academic year ranging from a low of $\$ 3768$ for courses in the arts, humanities, social sciences, education, and nursing, to a high of $\$ 6283$ for law, medicine, dentistry, and veterinary science. A middle band of $\$ 5367$ exists for students studying the sciences, mathematics, computing, other health sciences, agriculture, architecture, engineering, and business. Graduates begin repayment when their annual income reaches the minimum threshold of $\$ 25,348^{2}$; individuals earning over $\$ 45,629$ are subject to the maximum HECS payroll deduction of $6 \%$ of gross pay (DEST 2003). ${ }^{3}$

Although HECS was ostensibly introduced partially as a means of broadening access to higher education, the scheme has been and continues to be criticized as a possible barrier to participation in higher education for persons of lower socioeconomic status, who have historically attended university in much smaller numbers compared to individuals of greater means. A number of studies have been conducted over the past 15 years in an attempt to determine the extent to which HECS has exerted a negative influence on enrollments (Andrews 1997, 1999; Bardsley 1989; Clarke et al. 1997; James et al. 1999; Ramsey et al. 1998; Robertson and Sloan 1990). Studies have generally found the impact of HECS to be slight to negligible, with mature-age or nontraditional students the mostly likely individuals to alter their decision making as a direct result of HECS.

\section{The experiences of Australian students}

Much of the research that has been conducted in an attempt to understand the class-based higher education participation gap is primarily quantitative, and based on analyses of national or institutional 
surveys and other economic and financial data. At the same time, a number of qualitative studies of low-income students at American universities have attempted to gain insight into the particular and idiosyncratic factors and life circumstances of individuals that are best captured through narrative, ethnographic, and phenomenological inquiry (Caldwell and Trainer 1989; Eyermann 1995; Hossler et al. 1999; Institute for Higher Education Policy 2001; Lawrence 1996; Levine and Nidiffer 1996; Macy 2000; McDonough 1997). The methodology employed in these studies was used in the conceptualization and design of an original research initiative conducted in an Australian context and summarized in this paper.

The study was conducted during a nine-week, grant-funded trip to Australia by an American researcher during the (northern) summer of 2001. Sixteen participants were chosen for the study - four from each of four different universities. The particular institutions were chosen to represent the major forms or types of universities found in the Australian higher education system. In addition to their diverse histories, missions, and academic programs, the selected institutions have comparatively distinct student profiles, enrolling differing percentages of students from lowsocioeconomic backgrounds. The four universities are referred to in the study as Established, Suburban, Regional, and New (McInnes et al. 2000).

Study participants were identified through purposive sampling techniques (Patton 1990) with assistance from university staff associated with equity and access initiatives at each of the four institutions. An applicant was identified as having a low-socioeconomic background if he or she qualified for government means-tested educational or family support benefits both in high school and while at university, and if neither of his or her parents had earned a bachelors degree. Selection of participants was made with a desire for a broad representation of students by academic area, age, gender, and family status, consistent with Patton's (1990) recommendations for 'intensity' and 'maximum variation sampling' to help insure an information-rich collection. The eventual pool of study participants included nine women and seven men, of ages ranging from 19 to 29. A summary of the participants' institutional affiliation, gender, age, and academic course(s) can be found in Appendix A.

Interviews were conducted using a semi-structured format, utilizing a combination of pre-determined questions in order to generate specific desired information from all of the participants, and unstructured dialogue that provided individuals with the opportunity to share their experiences and tell their stories in unique and personal ways (Merriman 1998). Interviews lasted between 50 and $105 \mathrm{~min}$ in duration. All 
interviews were audio taped, with all but three transcribed by the researcher. Copies of interview transcripts were sent to participants for review and commentary.

Interview data was analyzed through a three-step process of description, analysis, and interpretation (Creswell 1998) using the constant comparative method and coding procedures commonly associated with grounded theory research (Strauss and Corbin 1998). Information from interviews was collapsed into progressively smaller pieces of data, then categorized and analyzed for specific patterns. The resulting patterns were then connected to larger themes, with the data being reconceptualized in new ways to reveal insight into the meanings of participants and to enable interpretation of the significance of individual lived experiences to members of the outside world. Transcripts were coded, organized, and analyzed with the assistance of QSR NVivo, a computer software package commonly used by researchers to assist in the management of qualitative data.

\section{Research Findings}

The student interviews covered a broad range of issues related to the development of educational aspirations and how beliefs and attitudes about cost influenced participants' understanding and decision making regarding postsecondary opportunities, university search, application and enrollment, and postbaccalaureate plans. Included in the interviews were questions concerning cost awareness, about strategies employed to successfully manage the financial element of university study, and regarding participants' specific experience with and perceptions of HECS.

As would be expected, a number of discreet and related themes emerged from analysis of the 16 interviews. In addition to the above topics, patterns that appeared in the transcripts included motivations for attending university; pre-university cost considerations; self-assessments of skills, abilities, and personal traits and characteristics; general financial orientation; pre-university experiences and influences; and the role of significant others including family, peers, teachers and other school staff. However, given the total volume and scope of the interview data, only those sections or themes that relate directly to the research focus of this paper are described and analyzed below.

Although not specifically related to HECS or general costs per se, an examination of the influences that participants reported on the 
development of their educational aspirations provides a good introduction to their histories and social positions, which can in turn help to contextualize later discussions about the role of cost in decision making.

\section{Influences on university ideation}

When asked when they first thought about attending university, many of the participants struggled to identify a time or event when they were convinced of the notion that higher education was a part of their future. Even though most identified Year 10 of school as a key time when they began to make specific plans to attend university, a number of students stated that they 'always knew' they would attend, and that this sense had existed within them from an early age. While for some this notion was connected to aspirations for a specific vocation or career, for others it was related more to a general love of learning or positive feelings about the educational process. A number of students indicated that university study was for them something of a foregone conclusion - that it was taken for granted that one would go to college in order to be able to secure a good job or otherwise achieve success in life.

Gail was one of the students who expressed that she 'always knew' that university studies were in her future. When asked where she thought that notion had originated, she stated:

I don't really know, because neither of my parents were big on education. I'm not sure whether I got it from the school, from the teachers, or just from myself. Like I've always had good, high goals set in life that I want to get through and achieve. I don't know, it's just always been one of those things. I've always enjoyed school, so I've always had a good opinion of it, even if I don't do well in some things. I've never looked at it badly or anything like that. So I guess I always knew. And I'm the first one in my family to go to University.

Wendy described how her parents, who immigrated from Vietnam, pushed her to gain the experiences that were unavailable to them in their country of origin:

They say they couldn't, they really wanted to go to school in Vietnam but because of family circumstances, they were poor, they have to help out with their family, so they couldn't attend, and maybe that's why they couldn't get a good career, and that's why their life is poor, so that's why they say you have to go to uni to get 
a good job, and then you get a better life. Yeah, that's what they always tell me.

Knowledge of cost and the influence on university planning and decision making

Participants were asked when they first became aware that attending university would involve costs, and how they determined that higher education was within their financial reach. While some students professed having a vague notion of required fees while growing up, the majority indicated that the specifics were unknown to them until their final years of high school, when they began to more intently read and seek out information about higher education. The participants generally expressed limited worry about being able to afford university, given the option to defer HECS, and for many, the knowledge that they could continue to live at home. Even when the specific costs were unknown, students expressed a confidence that things would somehow work out that they could marshal the necessary resources to get by.

Students from country areas reported being concerned about the potential costs associated with relocating for their education, particularly if this meant moving to one of the major cities. Two students noted that they chose to attend Regional University rather than an urban institution partly because of the perceived higher costs of rent and transport, a phenomenon that was also observed by James et al. (1999) in their study of rural and isolated students. Alice noted how the cost of living became a primary factor in her ultimate university choice:

The HECS didn't phase because it was an option, it was never going to be paid up front, it was always going to be deferred. Just the cost of living in general I think really is what came into it, yeah ... I looked at the fact that I was going to have to fork out $\$ 90$ a week rent in (the city) compared to $\$ 40$ in (regional town), and that's a big difference.

Richard had a very similar reaction to the possible costs faced in the city versus those associated with Regional University:

Cost was, the actual cost of education and HECS wasn't a concern, it was more of the living expenses and travel. As I mentioned before I didn't really have a place to stay in (the city) that was close enough to the campus ... I didn't have a car, I didn't have enough money 
saved up, I didn't have a job down there that I could go to, so that was a major concern was the financial side of things, and that's why I did end up choosing (Regional University).

\section{Advanced financial planning and strategy development}

Participants were asked about the extent of thought and planning they devoted to the task of securing the necessary financial resources to attend university. A number of students indicated that in preparation for university they began or continued to save money earned through part-time employment and received through government support programs such as Youth Allowance. Others indicated that they felt they could fall back upon their parents or other relatives for financial support in the event of need, even if the availability of such emergency funds was never explicitly communicated.

Perhaps most intriguing were the students who expressed a faith that everything would work out - that between their own resources, government support, and possible assistance from family, they could accumulate the necessary funds to get by. Associated with this belief was a conviction that university study was something of such value that one would find a way to realize the opportunity, whatever that might require. Linda communicated this value quite clearly in explaining how she decided to obtain a significant personal loan to cover the cost of a transitional program for students who were entering university after a period of absence from formal educational systems:

It's something I really, really wanted to do, and yeah, if I want something I'll do it. It was a bit scary getting a loan for that kind of cash, but it's worth it to me, to be able to go on and do what I want to do and actually get a degree and have a profession and a career and a life, as opposed to what I could do and just sort of like do, be a secretary five days a week and do that every day for the next thirty years, yeah I'm sure that would be fun, but (laughs), I'd rather do this. I have strong personal goals and high expectations and I know that I can do it, and if I didn't do it then I just wouldn't be happy with myself.

Even when asked if the absence of a deferred payment system would have caused them to make different choices, a number of participants shared that they still would have done the required planning and made the necessary sacrifices in order to acquire the resources to attend 
university. Students suggested that the existence of mandatory up-front payments would have forced them to rely on parents or devote more time to paid employment while in school, and/or to defer their studies for one or two years in order to earn enough income to pay for university. Gail was typical of the students who communicated this 'whatever it takes' perspective on university study, even when faced with the prospect of not being able to defer her HECS:

I would have had to plan ages ago, like years working and just saving for that and only that. I wouldn't have had anything for extra.

Interviewer: Do you think you still would have gone to university?

I probably would've. I think I would've still made the sacrifice, saved up and gone for it no matter what. It's just the sort of person I am. But I know lots of people that wouldn't. Just depends on the person that you are.

\section{Influence of HECS on decision making}

Much of the criticism of HECS concerns the extent to which an aversion to debt prevents some individuals from choosing to attend university. While this may be an issue for some prospective students, few of the participants in the study indicated that the level of HECS charges or the prospect of significant debt upon graduation was a particular worry. One exception was Brian:

I think if it was so expensive to start off with, I would have thought, there's no way. Where I was and who I was when I began, I thought, I couldn't imagine myself in the end being the lawyer or being whatever, and therefore it's hard to imagine myself being able to afford in the end, to pay the debt off in the end. So if it was too high initially it quite possibly would have scared me off. Knowing that it was in a reasonable range, I thought even if, even if I failed and I didn't end up being what I wanted to be, just a dull nine-to-five whatever job, over a long enough period it would pay the debt off anyway.

Alice distinguished between long-term debt and short-term expenses, which were of more immediate concern:

It was always going to be deferred, I couldn't dream of, four and half thousand a year, or five thousand a year I think it is I mean for HECS, I couldn't even dream of having that much money to pay for 
it, yeah ... I just thought, hmm, defer it, don't worry about that, (miscellaneous) fees are the things I've got to worry about.

As noted earlier, the 1996 HECS system was modified such that fees were differentiated by course, with nursing, education, and arts in the lowest band, medicine, law, and veterinary science in the high band, and most other courses, including science and business, in the middle range of costs. In no case did a participant indicate that he or she made a decision to pursue a particular academic course because if its lower positioning on the HECS scale. Rather, students consistently expressed a conviction that university study in general, and in some cases a particular course or career goal, were of such importance that cost was of limited concern, if not irrelevant. Some students admitted that they were in fact unaware during the university search and application process that HECS fees differed by course. In other cases, participants noted an early desire to pursue a specific career or vocation and applied for relevant courses without concern for their costs compared to other options of study. Students pursuing more expensive courses expressed general confidence that their education would lead to jobs that provided enough income to enable the repayment of debt without difficulty.

Rachel described her thought process when trying to decide between a course in biological science and one in nursing:

I always knew that becoming a doctor, lawyer, those sort of things cost a lot. I didn't really even think about the cost at all. If it was something I wanted to do, I'd find my way to pay for it. I didn't pick nursing because it was cheap or it was expensive or anything like that. That sort of didn't go into it. I just knew that any course I'd do I'd have to work to earn enough money.

Some students rationalized their choice to pursue more expensive courses as investments, indicating their belief that the extra money being spent on a particular program would pay off in the form of increased professional opportunities and/or higher salaries. Gregg justified his decision to pursue a double major in this manner:

All I thought was that it would take me an extra year. And I thought that I'd be more suited to whatever I wanted to do, like more qualified I guess. Like why do one, why do one degree and maybe expose yourself to $50 \%$ or $70 \%$ of the jobs, when you can do two degrees for an extra year and get $90 \%$ of the jobs, or exposed to more? So the whole thing was, like I said before, opening myself up to more things. 


\section{Financial orientation and relationship to debt}

A general theme of financial independence emerged for many of the students in the study. In addition to communicating a general dislike for borrowing money from parents, a number of students expressed a general desire to avoid being indebted to others, while some specifically noted their disapproval or even disdain for peers who lived lavish or seemingly carefree lifestyles at the expense of their parents. Related to this theme was an expressed sense of satisfaction or comfort with the knowledge that one's hard work and self-reliance would ultimately prove to be beneficial, and serve as a learning opportunity to provide participants with a better appreciation of their experience.

Rachel was one of the students who expressed a desire to exhibit responsibility for her own finances rather than rely upon her parents for support:

I don't always like taking money from my parents. I'd rather do it myself. In contrast to my friend who doesn't get a lot of help from her parents but gets more money from the government, and she hasn't had a job and stuff like that. I don't know, I just feel like I should be working to pay my way. But I don't know where it's come from.

In addition to her work ethic, Rachel noted that she had "always been a saver". When asked where this trait developed, she stated:

I think not having much money as a family when we were younger. So I decided to save. My mum's always said, you know, save as much money as you can. I get it from my grandfather as well, he's always saying 'spend half, save half', so I tend to do that, unless I have to buy food and pay rent, then I don't get to save much . . . if I wanted to go to university I had to save up.

Bill described his feelings about having to work to support himself while his peers were afforded the luxury of parental support:

I'd look around at my friends and other people that were going there, and I'd just think, you don't know what it's like, because they were doing really well but they could study every weekend, and they could go home and do nothing basically, and their parents would pay for everything, and that really used to piss me off ... what made me think it was all worth it was, hey I'm doing this for myself, when I finish this I'll come out of it not just with a degree but with real life experience. 


\section{A 'Tipping Point'}

When asked if there existed a 'tipping point' of sorts - a level of fees that would cause one to reconsider if the benefits of university study were worth the amount of costs incurred-students were generally of the opinion that if higher education was important enough, one would find a way to make it work. The fact that repayment would be made in relatively small increments and contingent upon their earnings was an important variable for a number of students in their assessment of the relative affordability of university costs and payoff of their investment. When pressed to identify what might constitute an 'unreasonable' level of fees, students often struggled with the task, occasionally noting that the non-tangible or 'amorphous' nature of the debt made such assessments difficult. When able to offer a benchmark, students suggested limits in terms of either dollars or in the time required to pay off one's obligations.

When asked at what point he would begin to question whether HECS was a worthwhile investment, Todd stated:

I reckon about probably double. If it was $\$ 4,000$ a semester, you would really start-like they're starting to be big costs. You know, you start thinking, what else could you do with that money, you know? And yeah, you really would have to think, I'm getting ... almost $\$ 10,000$ a year in debt. I think those sort of big numbers really have an effect on people, when they think about those.

Rachel framed her response to the question by indicating what she felt was an unreasonable timeframe for repayment:

Probably any more than five years or something. At this stage I'd be able to pay it off by then. Any more than 10 years is ridiculous. Ten years or more to have to pay it off. I guess the idea is that you save up right from the start, and then you don't have to pay anything at all. At this stage I'm aiming for five years. Any more than that, I don't want to really look at.

\section{Repayment of HECS debt}

Students generally expressed little worry about the repayment of their HECS. Most communicated a reasonably accurate understanding of the process by which repayment is made, including the minimum earned income threshold required before the government initiates collection, and the relative percentage that is deducted from one's pay. Some 
students expressed a desire to postpone thinking about repayment until the necessary time arrived. One student acknowledged that she didn't even open any of her HECS statements until her second year at university. Another student in this category expressed his faith that "providing I leave here with the skills that I can maintain my job, and that my wage goes up each year, as they tell me it's meant to, I don't really, it's not something I try to think about."

One student who possessed experience paying back HECS after a previous stint at university noted that the amount of the deduction was relatively insignificant compared to the other income taxes that are withdrawn from one's pay. Other students suggested that since they had little to no experience as full-time wage earners, and were accustomed to having minimal disposable income, they would likely take little notice to the HECS deduction from their pay. Alice was among those students who indicated that they did not anticipate that paying back HECS would be a problem, claiming "I'm going to be so rich when I start working compared to what I am now" that her HECS payments would barely be noticed:

It doesn't phase you, it's just that little extra bit, and when you stop paying it you'll think, oh, I've got a bit extra. But no, it doesn't phase me . . . I'll be more financially stable then. Like, if I can find five dollars a week now on such a tight budget to be able to pay off my kitchen table and chairs, then earning $\$ 500$ a week trying to find $\$ 40$ is much, much less, it's like trying to find 20 cents now.

While most students expressed confidence that they would not be overly burdened or encumbered by HECS debt upon graduation, Susanna represented an exception:

I (thought) it was going to be probably around $\$ 20,000$ by the time I got out, but I think it will probably be more around the $\$ 10,000$ mark, but that's still a bloody lot of money. I was talking to one nurse for I don't know how many years, and he still hasn't paid his off, so it's really scary ... I'm just scared I won't be left with a comfortable wage after working so hard at uni, you know what I mean? I just have to wait and see, or I suppose I could try and find out about it.

For a number of participants in the study, the notion of HECS indebtedness was difficult to grasp. Drawing comparisons to consumer debt such as mortgages and auto loans, students found HECS to be rather amorphous, or 'out of sight, out of mind'. One student laughed while sharing that she would likely be in some form of debt for most of 
her life, and that a $\$ 12,000$ HECS obligation was of little concern compared to a $\$ 200,000$ home loan. One student went as far as referring to HECS as a joke, noting that to him and many of his friends, HECS wasn't seen as a 'real' debt compared to money borrowed for material consumer purchases. Gregg suggested that HECS was an investment comparable to other major life investments:

Five years of education is like $\$ 25,000$, it's a fair bit of money. So it's going to be a lot to pay off, but I guess it's like personal assets, you think you've got a car, a house, and you've got a university qualification, it's just one of the things that is kind of a prerequisite to success in today's society perhaps.

\section{Discussion of student interviews}

Students who participated in this study expressed little to no worry about the debt they would incur through HECS, indicating in most cases that the prospect of indebtedness was generally not significant in their decision making about higher education. Participants expressed a general confidence that the required payments would not be burdensome given the minimum salary threshold built into the system and the relatively low percentage of their incomes that would be deducted by their employers for HECS purposes.

Related to the sense that HECS was affordable was a notion communicated by the majority of participants that HECS was in some ways amorphous, lacking the feel of a 'real' debt. For some students, this was due to the fact that nothing of material substance had been purchased or received in the process, unlike the debt incurred when one buys a house or an automobile. For other students, HECS lacked temporality their graduation and concomitant repayment obligations were far enough in the future to render HECS relatively meaningless to one's present state of affairs.

The lack of a physical, tangible, or otherwise visceral experience of currency or value exchange has been identified as a weakness of the current HECS system by individuals who propose that Australia move to a 'voucher' system that might also be accompanied by a granting of authority to individual universities to set their own tuition rates. These two conditions, it is argued by voucher proponents, would benefit universities and students by introducing traditional market forces into higher education, allowing prospective students to be more savvy consumers of educational products through the ability to shop around for 
the best prices and the 'best' courses, and forcing universities to devote much greater attention to cost control and to providing more efficient, higher quality programs and services.

In keeping with the theme of the 'amorphous' nature of HECS, many participants also admitted lacking detailed knowledge, past or present, about the specifics of the HECS system. This was confirmed by the factually inaccurate information provided by a number of students in response to questions about their understanding of and experience with HECS. This in itself is an issue worthy of further exploration, particularly if inaccurate information or misunderstandings about HECS is a contributing factor to the continued socioeconomic gap in Australian universities.

Many of the students shared that while HECS was a minor or even non-issue during their university search and exploration process, they were quite concerned about the affordability of related costs of study, specifically the amount of money required for accommodations and other living expenses. This was a particular concern for individuals from rural and outstate areas, for whom living costs can be a significant factor in the college decision process, affecting choice of institution and even the more basic question of whether or not to pursue higher education.

Since the universities of generally perceived higher quality and greater overall prestige are located almost exclusively in capital cities, it is possible that the concern about living costs is contributing to the perpetuation of social stratification within Australian society by keeping lower-SES individuals in second- and third-tier institutions. Universities can begin to address this issue by communicating with students more clearly regarding the specific costs they can expect to incur for housing, including those associated with different options for accommodation in and around university campuses. Scholarships to allow rural and lowincome students to live in university colleges and halls of residence, and increases in government rent assistance, might also help to address the reluctance of disadvantaged students to travel to capital cities for their education due to the perceived unreasonable cost of living.

Aside from the cost of housing and related living expenses, many participants in the study expressed a lack of prior knowledge of the general panoply of fees and expenses discovered upon enrolling at university. Students require much better information regarding student union charges, service fees and other costs typically incurred at university so they can better plan to cover such expenses and reduce any surprises they might otherwise experience. While a number of students reported having managed to build savings for university through employment, 
government benefits, or other means, others arrived on campus with little to no money to cover immediate expenses. While some expressed confidence that parents or other relatives would come through with financial assistance if needed, not all students possessed such a backup. In addition, many students reported barely getting by while in school, indicating that their resources from paid work and maintenance payments were hardly enough for them to manage without having to beg or borrow money from other sources. While one strategy to address the gap between student needs and student resources would be to expand eligibility for Youth Allowance, another would be to allow students to receive a certain amount of income at the beginning of each semester that would be added to their overall HECS debt. In this way, students would have access to the cash needed at a time when multiple expenses are incurred (fees, books, parking permits, concession cards, supplies, etc.). This also would allow students to avoid the penalties of interest associated with bank loans, credit cards, or existing government-supported loan programs.

\section{Limitations of the study}

A common approach to the study of the tertiary decision and enrollment process is to focus on the 'success stories' - those students who manage to overcome poverty and various other social and structural barriers to attend university. The study discussed in this paper is to some degree consistent with the 'success story' genre in its focus on enrolled students. This approach has limitations in that it focuses only on those students who are already at university - those who possess the requisite combination of skill, motivation, and luck, and have therefore 'made it' (Orfield 1992). While the study of success stories is important in gaining an understanding of how to help others in similar circumstances, this line of research provides limited insight into those who have been excluded from the higher education system, either by financial restraints, sociocultural forces, or psychological variables that directly or indirectly influence their decision to pursue options other than university. An important follow-up to the research reported in this paper would be to interview a group of individuals similar to the participants in this study but who pursued paths other than higher education, in an attempt to identify the variables and themes that influenced their postsecondary planning and decision making.

As with most qualitative research, this study is designed to illuminate the perceptions, beliefs, and lived experiences of a specific group of 
individuals within a particular temporal and situational context. The 'results' are not designed to be generalized to a larger population, nor should the voices of the 16 individuals in this study be viewed as necessarily representative of all low-SES and/or first-generation university students in Australia. Rather, the themes that emerged from the stories shared by the participants are meant to be illustrative of the types of phenomena that exist in the lives of some individuals of low-socioeconomic status as they consider, plan for, enroll in, and experience higher education. However, the findings from this study can also be utilized to help design larger-scale research initiatives regarding low-SES individuals and the university decision process, perhaps through informing the construction of a survey designed to be a more comprehensive measure of the issues and concerns facing low-SES school students as they consider the option of higher education.

\section{Conclusion}

As has been shown through a review of related literature and an in-depth qualitative study of the experiences of students in Australia, a HECStype system can result in numerous benefits to both national governments and participants in higher education and can be used as a model for countries that are trying to address problems related to inequitable access to higher education. While a number of particular economic, political, and cultural factors enable the system to work effectively in Australia, these variables may not exist in the same form in other nations. A number of critical issues would need to be addressed before a system similar to the Australian HECS model could be implemented in countries possessing the required resources and necessary infrastructure. These include the role of private financial institutions in student support programs; the potential scope and cost of an income-contingent loan scheme, and the opportunity to conduct pilot studies, perhaps in a single or small number of states, provinces, or universities.

Governments must devote serious consideration to the limits of financial strategies to address sociocultural problems related to higher education. As discussed in the conceptual framework for this paper, the continued socioeconomic gap in university enrollments is a function of numerous and wide-ranging factors. While a lack of adequate financial resources undoubtedly keeps millions of otherwise qualified and capable individuals out of universities, many other psychological, sociological, cultural, and structural variables also are involved in maintaining, if not 
exacerbating, class inequality in higher education. For example, debt aversion and related sociological barriers to higher education will likely not be solved through the implementation of an income contingent loan scheme. Rather, these issues require additional and varied uses of time, talent, and financial resources to discuss, research, and problem solve for the long-term benefit of society.

Given the role of education in promoting economic development and social mobility, it is important to more fully understand the process by which certain individuals decide that the benefits of a university degree outweigh the various costs of attendance. Additional research can assist a wide variety of individuals who help shape the educational aspirations and opportunity structures of youth - parents, teachers, and school guidance and careers counselors among others - to better recognize and understand the needs and concerns of adolescents and the various forces that influence thinking about future plans and goals. This knowledge can enable those who teach, counsel, encourage, mentor, and motivate youth to do so in a manner that communicates empathy and understanding while expanding students' views of what is possible and achievable. University admissions and promotion officers might apply the insight gained from research to the development of more effective educational outreach initiatives. Research might also assist public policy makers in creating programs that more successfully target talented, lower income youth and promote access to various forms of educational opportunity. These efforts are necessary to help reverse the trend of talent wastage among the low-income youth of many nations, to improve the lives of individuals by removing obstacles in the pursuit of their goals and aspirations, and to promote stronger, more cohesive societies for future generations.

\section{Acknowledgements}

The research was supported by funds provided through a University of Michigan International Institute Pre-Dissertation Research Award, and a University of Michigan School of Education Spencer Foundation Research Training Grant. The information and analysis presented in this paper do not necessarily reflect the opinions or positions of the University of Michigan or its constituent units. An earlier version of this paper was presented at the annual meeting of the Association for the study of Higher Education, Sacramento, California, November 2002. The author wishes to acknowledge Craig McInnis and the staff of the 
Centre for the Study of Higher Education at the University of Melbourne, who provided invaluable support and advisement during the research process.

Appendix. List of participant pseudonyms, age, academic course, and affiliated University

Established University

Aaron $\quad 27$

Andrea 21

Brian 28

Gregg

19

New University

$\begin{array}{lll}\text { Adam } & 21 & \text { Science } \\ \text { Gail } & 21 & \text { Education } \\ \text { Melissa } & 29 & \text { Science } \\ \text { Wendy } & 19 & \text { Business }\end{array}$

Regional University

\begin{tabular}{lcl} 
Alice & 19 & Nursing \\
Richard & 19 & Arts \\
Sharon & 21 & Nursing \\
Todd & 27 & Computing \\
Suburban & University & \\
Bill & 25 & Computing \\
Grace & 19 & Nursing; \\
& & Science \\
Linda & 24 & Education \\
Rachel & 20 & Nursing \\
\hline
\end{tabular}

Law; Arts

Science

Law; Arts

Science; Arts

Science

Science

Business

Nursing

Nursing

\section{Notes}

1. The rate of currency exchange as of 19 February, 2004 was A $\$ 1.00=$ US $\$ 0.791=$ 0.622 euros. All monetary figures are listed in Australian dollars.

2. For comparison purposes, the average annual earnings of full-time workers in August 2003, extrapolated from average weekly earnings, was $\$ 50,663$ (Australian Bureau of Statistics, 2003).

3. The repayment threshold is scheduled to rise to $\$ 35,000$ in 2005 and $\$ 36,184$ in 2006 .

4. The recently passed "Higher Education Support Act of 2003" will result in a number of significant changes to enrollment, cost, and repayment structures within the university sector, including the expansion of 'full fee' student places, an increase in the HECS repayment threshold, additional support for rural students, an expansion of 
loan programs for graduate students and expanded institutional authority set tuition levels. The controversial legislation has been targeted by leaders of the Australian Labor Party, who have promised significant changes if it returns to a majority in Parliament as a result of the federal election slated for late 2004.

\section{References}

Andrews, L. (1997). Effect of HECS on Interest in Undertaking Higher Education. Canberra, Australia: Department of Education, Employment, Training, and Youth Affairs.

Andrews, L. (1999). Does HECS Deter? Factors Affecting University Participation by Low-SES Groups. Canberra, Australia: Department of Education, Training, and Youth Affairs.

Aungles, P., Buchanan, I., Karmel, T. and MacLachlan, M. (2002). HECS and opportunities in higher education: a paper investigating the impact of the Higher Education Contribution Scheme (HECS) on the higher education system. Retrieved February 19, 2004 from http://www.dest.gov.au/directory/media/reports/hecs.htm.

Australian Bureau of Statistics (ABS) (2003, November 11). "Average Weekly Earnings, Australia". Retrieved February 19, 2004 from www.abs.gov.au.

Baker, T. and Valez, W. (1996). Access to and opportunity in postsecondary education in the United States: A review. Sociology of Education 69(1), 82-101.

Bardsley, N. (1989). Impact of the Higher Education Scheme - Survey Report Western Australia. Canberra, Australia: Department of Employment, Education, and Training.

Caldwell, C.A. and Trainer, J.F. (1989). An ethnographic study of low participation rates in higher education in southcentral Pennsylvania. Paper presented at the annual meeting of the American Educational Research Association, San Francisco, California.

Carpenter, P.G. and Western, J.S. (1984). Transition to higher education. Australian Journal of Education 28(3), 249-273.

Clarke, J., Zimmer, B. and Main, R. (1997). Under-representation in Australian higher education by the socio-economically disadvantaged: Review of trends and practices, and implications for university planning. Paper presented at the Australasian Association for Institutional Research 8th International Conference, Adelaide, Australia, November 1997.

Creswell, J. W. (1998). Qualitative Inquiry and Research Design: Choosing Among Five Traditions. Thousand Oaks, CA: Sage.

Department of Education, Science, and Training (DEST) (2002). Higher Education Report for the 2002 to 2004 Triennium. Retrieved February 19, 2004 from www.dest.gov.au/highered/he_report/2002_2004/html.

Department of Education, Science, and Training (DEST) (2003). Higher Education Report for the 2003 to 2005 Triennium. Retrieved on-line February 19, 2004 from http:// www.dest.gov.au/highered/he_report/2003_2005/pdf/triennium2003_2005.pdf.

Department of Employment, Education and Training (1993). National report on Australia's Higher Education Sector. Canberra, Australia: Australian Government Publishing Service. 
Eyermann, T.S. (1995, November). Destiny Challenged: Cost and Choice Factors Related to Low Income Student Matriculation at a Private Institution. Paper presented at the annual meeting of the Association for the Study of Higher Education, Orlando, FL.

Hauser, R.M. (1992). The decline in college entry among African-Americans: Findings in search of an explanation, in P. Sniderman, P. Tetlock and E. Carmines (eds.), Prejudice, Politics, and Race in America Today. Palo Alto, CA: Stanford University Press, (pp. 271-306).

Heyden, M. and Carpenter, P. (1990). From school to higher education in Australia. Higher Education 20, 175-96.

Hossler, D., Schmit, N. and Vesper, N. (1999). Going to College: How Social, Economic, and Educational Factors Influence Decisions Students Make. Baltimore: Johns Hopkins University Press.

Institute for Higher Education Policy (2001). Getting Through College: Voices of Lowincome and Minority Students in New England. Washington, DC: Author.

James, R., Wyn, J., Baldwin, G., Hepworth, G., McInnis, C. and Stephanou, A. (1999). Rural and Isolated School Students and their Higher Education Choices: A Reexamination of Student Location, Socioeconomic Background, and Educational Advantage and Disadvantage. Commissioned Report No. 62. Canberra, Australia: National Board of Employment, Education and Training.

Johnstone, D.B. (2001a). The Economics and Politics of Income Contingent Repayment Plans. Buffalo, NY: Center for Comparative and Global Studies in Education, State University of New York.

Johnstone, D.B. (2001b). Student Loans in International Perspective: Promises and Failures, Myths and Partial Truths. Buffalo, NY: Center for Comparative and Global Studies in Education, State University of New York.

Johnstone, D.B. and Shroff-Mehta, P. (2000). Higher Education Finance and Accessibility: An International Comparative Examination of Tuition and Financial Assistance Policies. Buffalo, NY: Center for Comparative and Global Studies in Education, State University of New York at Buffalo.

Karmel, T. (1999). Financing Higher Education in Australia. Canberra, Australia: Department of Education, Training and Youth Affairs.

Lamb, S. (2001). The Pathways from School to Further Study and Work for Australian Graduates. Longitudinal Study of Australian Youth Report 19. Melbourne, Australia: Australian Council for Educational Research.

Lamb, S. and McKenzie, P. (2001). Patterns of Success or Failure in the Transition from School to Work in Australia. Longitudinal Study of Australian Youth Report 18. Melbourne, Australia: Australian Council for Educational Research.

Lawrence, B.K. (1996, October). Working Memory: An Ethnographic Case Study of the Influence on Culture on Education. Paper presented at the annual meeting of the National Rural Education Association, San Antonio, TX.

Levine, A. and Nidiffer, J. (1996). Beating the Odds: How the Poor get to College. San Francisco: Jossey-Bass.

Macintyre, S. and Marginson, S. (1998). The university and its public, in Coady, T. (ed.), Why Universities Matter. Sydney, Australia: Allen and Unwin.

Macy, B. (2000). From Rusty Wire Fences to Wrought-iron Gates: How the Poor Succeed in Getting to - and Through - College. Washington, DC: The College Board. 
Marginson, S. (1993). Education and Public Policy in Australia. Cambridge, UK: Cambridge University Press.

Marginson, S. (1997). Educating Australia: Government, Economy and Citizen since 1960. Cambridge, UK: Cambridge University Press.

McDonough, P.M. (1997). Choosing Colleges: How Social Class and Schools Structure Opportunity. Albany: State University of New York Press.

McInnis, C. James, R. and Hartley, R. (2000). Trends in the First Year Experience in Australian Universities. Canberra, Australia: Department of Education, Training, and Youth Affairs.

Merriman, S.B. (1998). Qualitative Research and Case Study Applications in Higher Education. San Francisco: Jossey-Bass.

Organization for Economic Cooperation and Development (OECD) (1998). Human Capital Investment: An International Comparison. Paris: Author.

Orfield, G. (1992). Money, equity, and college access. Harvard Educational Review 62(3), $337-372$.

Patton, M.Q. (1990). Qualitative Evaluation and Research Methods. Newbury Park, CA: Sage.

Ramsay, E., Trantor, D., Charlton, S. and Summer, R. (1998). Higher Education Access and Equity for low SES School Leavers: A Case Study. Canberra, Australia: Department of Education, Training and Youth Affairs.

Robertson, F. and Sloan, J. (1990). Impact of the Higher Education Contribution Scheme - Survey report Victoria. Canberra, Australia: Department of Employment, Education, and Training.

Strauss, A. and Corbin, J. (1998). Basics of Qualitative Research: Techniques and Procedures for Developing Grounded Theory. Thousand Oaks, CA: Sage.

Vossensteyn, H. (2001). Cost Sharing and Understanding Student Choice: Developments in Western Europe and Australia. Buffalo, NY: Center for Comparative and Global Studies in Education, State University of New York.

Address for correspondence: Phone: + 1-734-834-1619; Fax: +1-734-764-2510;

E-mail: cjrasmus@umich.edu 